\title{
Hybrid Arc Could Combine the Benefits of IMRT and VMAT to Deliver a Fast, Conformal, Homogeneous Treatment in Non-Small Cell Lung Cancer without Limitations of Low Dose Bath: A Planning Study
}

\author{
Yucel SAGLAM ${ }^{1,2}$, Yasemin BOLUKBASI ${ }^{3}$, Vildan ALPAN ${ }^{2}$, Erkan TOPKAN ${ }^{4}$, Steve KIRSNER ${ }^{5}$, \\ Matthew BALLO ${ }^{6}$, Joe Y. CHANG ${ }^{7}$, Ayhan BINGOLBALI ${ }^{1}$, Ugur SELEK ${ }^{2,3,7}$ \\ ${ }^{1}$ Yıldız Technical University, Department of Bioengineering, Istanbul, TURKEY \\ ${ }^{2}$ American Hospital, MD Anderson Radiation Treatment Center, Department of Radiation Oncology, Istanbul, TURKEY \\ ${ }^{3}$ Koc University, Faculty of Medicine, Department of Radiation Oncology, Istanbul, TURKEY \\ ${ }^{4}$ Baskent University, Adana Faculty of Medicine, Department of Radiation Oncology, Adana, TURKEY \\ ${ }^{5}$ University of Texas, MD Anderson Cancer Center, Department of Radiation Physics, Houston, USA \\ ${ }^{6}$ University of Tennessee, Health Science Center, Department of Radiation Oncology, Tennessee, USA \\ ${ }^{7}$ University of Texas, MD Anderson Cancer Center, Department of Radiation Oncology, Houston, USA
}

\begin{abstract}
Intensity Modulated Radiotherapy (IMRT, step and shoot) is emerging as the standard of care in non-small cell lung cancer (NSCLC) patient treatments. Volumetric Arc Therapy (VMAT) delivered with two arcs offers fast and homogeneous dose delivery with known limitations of increased volumes of low dose. The aim of this study is to define whether Hybrid volumetric arc IMRT (HA-IMRT: IMRT and VMAT combination) offers a superior dose distribution over IMRT without the limitations found in VMAT delivery alone. Ten (previously 4DCT planned) locally advanced NSCLC patients treated by IMRT to 70 Gy in 35 fractions were retrospectively re-planned using the HA-IMRT technique. Respiratory correlated imaging (3 mm slice thickness) were generated utilizing the Philips Large Bore 16 slice CT Scanner (Phillips, Inc.). Treatment planning was performed using The Philips Pinnacle Treatment Planning System v. 9.0 (Philips Medical, Cleveland, OH). The PTV was defined as the Integrated Tumor Volume (ITV= internal GTV contoured on all respiratory data sets plus $8 \mathrm{~mm}$ margin for all histologies) with a $4 \mathrm{~mm}$ margin added. Lung parenchyme was defined and contoured using the $50 \%$ phase. Conventional IMRT plans used 6:8 non coplanar or coplanar fields and VMAT plans were generated using two $180^{\circ}$ arcs. HAIMRT plans were generated using a combination of $60 \%$ conventional IMRT with $40 \%$ VMAT. The maximum dose (Gy) to the spinal cord, V5, V10, V20 for total lung, V20 and V30 for the ipsilateral lung, V30 for heart, V50and V70 for esophagus, and the V77 for the Clinical Treat Volume (CTV) were compared for all techniques utilizing the Dose Volume Histograms. In addition, total monitor units (MU), total treatment time (TT) and the conformality index (CI) were compared. . Conventional IMRT delivers less low dose to the lung compared to VMAT alone. (V5 VMAT (V5: $55.0 \%$ vs 63.0\%, $\mathrm{p}=0.005 ; \mathrm{V} 10: 41.4 \%$ vs $43.9 \%, \mathrm{p}=0.018$ ). However, VMAT is superior in total lung V2O (V20:30.6\% vs 29.3\% p= 0.010), ipsilateral lung doses (V20:55.5\% vs 52.8\% p= 0.008; V30: 46.1\% vs 42.9\% p= 0.012 ), and in heart sparing. (V30: $21.09 \%$ vs $17.78 \% p=0.015$; MHD: $15.92 \%$ vs $14.81 \% p=0.021$ ). It is also superior in conformality (Cl 1.51 vs $1.26 \mathrm{p}=0.005$ ) and treatment delivery is faster ( $293 \mathrm{~min}$ vs $108 \mathrm{~min} \mathrm{p}=0.005)$ with lower MUs (24805 vs $19141 \mathrm{p}=0.005)$. HA-IMRT was found to be superior to VMAT in terms of total lung low dose volumes (V5:58.1\% vs 63.0\%, $p=0.005 ; \mathrm{V} 10: 42.2 \%$ vs $44.9 \%, p=0.027$ ), superior to IMRT for ipsilateral lung doses (V20: 53.6\% vs 55.5\%, $p=0.007$; V30: 43.4\% vs 46.1\%, $p=0.018$ ), and superior in treatment time (199 min vs $293 \mathrm{~min}, \mathrm{p}=0.005$ ) with lower MU's (22155 vs 24805, $\mathrm{p}=.005$ ). Overall, HA-IMRT provides a more homogenous dose distribution (CTV: V77: $0.55 \%$ vs $2.1 \%$ vs $1.7 \%, p=0.000$ ) compared to IMRT and VMAT alone. All three plans provided comparable esophagus and spinal cord Organ at Risk (OAR) doses. HA-IMRT seems to combine the benefits of both conventional IMRT and VMAT; such as to deliver a faster, more conformal, homogeneous treatment in comparison to ssIMRT, and to deliver lower dose to lung in comparison to VMAT.
\end{abstract}

Keywords: VMAT, IMRT, Hybrid, Stage III lung cancer 
International Journal of Hematology and Oncology

ÖZET

Küçük Hücreli Dışı Akciğer Kanserli Hastaların Tedavisinde Hibrid Volümetrik Ark Radyoterapi, Yoğunluk Ayarlı Radyoterapi Ve Volumetrik Yoğunluk Ayarlı Ark Radyoterapisinin Avantajlarını Birleştirerek, Hızlı, Konformal ve Homojen bir Tedaviyi Düşük Doz Banyosundan Sakınarak Yapabilmektedir: Dozimetrik Çalışma

Küçük hücreli dışı akciğer kanserli (KHDAK) hastaların tedavisinde, Yoğunluk Ayarlı Radyoterapi (Step and shoot: YART) ve Volumetrik Yoğunluk Ayarlı Ark Terapisi (VMAT) giderek daha fazla kullanılmaktadır. Bu çalışmanın amacı, Hibrid volümetrik ark YART'ın (HA-YART: YART ve VMAT kombinasyonu) tek başına VMAT tedavisinde gözlenen sınılamalar olmaksızın, YART tedavisinden çok daha iyi bir doz dağıııı sunup sunmadığını belirlemektir. Dört Boyutlu Bilgisayarı Tomografi (4BBT) ile planlı, daha önceden YART ile 35 fraksiyon ile 70 Gy uygulanarak tedavi edilmiş lokal ileri evre KHDAK'li 10 hasta, HA-YART tekniği kullanılarak retrospektif olarak yeniden planlanmıştır. Philips Large Bore 16 dilimli BT (Phillips, Inc.) kullanılarak solunum kontrollü görüntüler (3mm kesit kalınlığı), Philips Pinnacle Tedavi Planlama Sistemi v.9.0 (Philips Medical, Cleveland, OH) kullanılarak tedavi planlamaları gerçekleştirilmiştir. PTV, İntegral Tümör Hacmine (ITV = tüm solunum fazlarında konturlanan GTV + tüm histolojiler için 8 mm) 4 mm marj eklenerek tanımlanmıştır. Akciğer parankimi solunumun \%50 fazında en küçük hacimde konturlanmıştır. Konvansiyonel YART planlarında, non-coplanar ya da coplanar 6:8 alanlar kullanıırken VMAT planları iki adet 180 arklar ile oluşturulmuştur. HA-IMRT planları için \%40 VMAT ile \%60 konvansiyonel YART kombinasyonu kullanıımışıı. Spinal kord için maksimum doz (Gy), toplam akciğer için V5, V10 ve V20, ipsilateral akciğer için V20 ve V30, kalp için V30, yemek borusu için V50 ve V70, klinik tedavi hacmi (CTV) için V77 değerleri tüm teknikler için Doz Hacmi Histogramları (DVH) kullanılarak karşılaştııımıștır. Ayrıca toplam monitör ünitleri (MU), toplam tedavi süresi (TT) ve konformalite indeksi (Cl) farklarına bakılmıştır. Konvansiyonel YART, VMAT'a göre daha az akciğer düşük doz değerleri sağlamaktadır (V5: 55.0\% vs 63.0\%, $\mathrm{p}=0.005 ; \mathrm{V} 10: 41.4 \%$ vs 43.9\% p= 0.018). Bununla birlikte, VMAT riskli organların korunmasında kritik eşikler gözetildiğinde, total akciğer V20'sinde (V20:30.6\% vs 29.3\% p= 0.010), ipsilateral akciğer dozlarında (V20:55.5\% vs 52.8\% p= 0.008; V30:46.1\% vs $42.9 \% p=0.012$ ) ve kalp dozlarında (V30: $21.09 \%$ vs $17.78 \% p=0.015$; MHD: $15.92 \%$ vs $14.81 \% p=0.021$ ) daha üstündür; aynı zamanda üstün konformalite (Cl 1,51 vs 1,26 p= 0.005) ve düşük MU (24805 vs $19141 \mathrm{p}=0.005)$ ile tedaviyi daha hızlı tamamlayabilmektedir (293 dak. vs 108 dak. $p=0.005)$. HA-YART'ın ise toplam akciğer düşük doz hacimleri (V5:58.1\% vs 63.0\%, p=.005; V10:42.2\% vs 44.9\%, $\mathrm{p}=0.027)$ bakımından VMAT'dan daha üstün olduğu, ipsilateral akciğer dozlarında (V20:53.6\% vs 55.5\% $\mathrm{p}=$ 0.007; V30: 43.4\% vs 46.1\% p= 0.018), daha az toplam MU (22155 vs 24805 p=0.005) ve daha kısa toplam tedavi süresiyle (199 dak vs 293 dak p= 0.005) IMRT'den üstün olduğu izlenmiștir. Genel olarak, HA-IMRT tek bașına YART ve VMAT ile karșılaștııılığında daha homojen (CTV: V77:0.55\% vs 2.1\% vs 1.7\%, p= 0.000) bir doz dağlımı sağlamaktadır. Her üç plan, kabul edilebilir ve benzer özofagus ile omurilik dozları sağlamıştır. HA-YART, ssYART'a kıyasla hızlı, daha konformal ve homojen bir tedavi sunmak için ve VMAT'a kıyasla daha az miktarda akciğeri daha düşük bir dozda ışınlamak için, hem geleneksel YART'ın hem de VMAT'ın faydalarını bir araya getirebilir.

Anahtar Kelimeler: VMAT, IMRT, Hibrit, Evre III akciğer kanseri

\section{INTRODUCTION}

Chemotherapy and Radiotherapy are accepted as "standard of care" for many locally advanced nonsmall cell lung cancer (NSCLC) patients. ${ }^{1,2}$ Standard radiation prescription doses have remained 60$63 \mathrm{~Gy}$ for more than 30 years except at a couple of comprehensive cancer institutions. ${ }^{2}$ Recently, analysis of seven different Radiation Therapy Oncology Group (RTOG) trials of chemo- radiotherapy for locally advanced NSCLC revealed improved survival and loco-regional control with dose escalation. ${ }^{3}$ Despite the benefits of radiotherapy, local control rates remained poor with standard doses leading to dose escalation to decrease local failure of disease, and to eliminate the primary source for distant metastases. However, the preliminary findings of RTOG 0617 comparing standard-dose (60
Gy) versus high-dose (74 Gy) conformal radiotherapy with concurrent chemotherapy for stage IIIA/ IIIB non-small cell lung cancer showed no survival benefit of dose escalation with 3DCRT or IMRT based on enrolling departments awaiting the technical analysis. ${ }^{4}$ This triggers the question of safe delivery of radiotherapy with developing technology in era of intensity modulated radiotherapy (IMRT), and volumetric arc radiotherapy (VMAT).

IMRT has been becoming the standard radiation treatment technique over the last decade, with the consequence of increased treatment time and the benefit of improved conformality and normal organ sparing. ${ }^{5}$ Recent secondary analysis of RTOG 0617 on impact of IMRT for Locally Advanced NSCLC supported the routine use of IMRT due to its impact on lower rates of severe pneumonitis and 



Figure 1. Field arrangements for (a) ssIMRT, (b) VMAT, (c) Hybrid-arc(ssIMRT+VMAT)

cardiac doses. ${ }^{6}$ VMAT is a relatively new treatment option which is an arc-based IMRT tecnique with a full 360 degrees of beam directions available for optimization. Preliminary results for treatment plans generated with VMAT optimization have displayed equivalent or superior dose distributions to static gantry IMRT plans. ${ }^{7,8}$

VMAT offers fast and homogeneous dose delivery with few studies on VMAT plan quality for stage III lung cancer. Quan et al. investigating an M.D. Anderson study of the emerging application of VMAT for stage III lung cancer in an automated way. ${ }^{9}$ In a study of comparision of intensitymodulated radiotherapy (IMRT) and volumetricmodulated arc therapy (VMAT) plans consisting 125 non-small cell lung cancer (NSCLC) patient's plans demostrated that IMRT may be better for NSCLC patients with poor pulmonary function while VMAT may be advised for NSCLC patients with normal pulmonary function. ${ }^{10}$ However, increased volumes of low dose compared to step and shoot IMRT (ssIMRT) is a limitation.

A combination of traditional conformal radiotherapy and double arc VMAT called the Hybrid rapid arc tecnique ${ }^{7}$ was evaluated by Chan et al to overcome the lung low dose bath. Superior dosimetry was demonstrated when compared with conformal radiotherapy and VMAT alone, while a hybrid IMRT (static plus IMRT beams treated concurrently) technique was noted to demonstrate advantages for reduction of low dose to lung. ${ }^{11}$ Based on those studies, we investigated whether Hybrid volumetric arc therapy as a combination of IMRT and VMAT (Hybrid ARC: IMRT and VMAT combination) offers a superior dose distribution over IMRT without the shortcomings of VMAT delivery alone.

\section{MATERIAL AND METHODS}

The planning 4D computerized tomography (4D CT) scans of ten consecutive stages IIIA- IIIB (UICC 6th Edition) NSCLC patients treated by definitive IMRT to 70 Gy in 35 fractions at our institution were retrieved. The details of simulation, volume definition, planning and comparison are given below.

\section{Simulation}

All patients were simulated in the supine position in a customized vac loc bed in addition to T-bar, Wing-board, and knee-foot stopper immobilization (CIVCO, Kalona, Iowa). 4-D and contrast freebreathing axial CT scans with $3 \mathrm{~mm}$ slice thickness from the mandible to the umbilicus were obtained with the Philips Brilliance Big Bore 16 slice CT 
(Phillips,Inc.). Respiratory correlated imaging was generated for planning which was performed using the Philips Pinnacle Treatment planning system (9.0, Philips Medical Systems Inc. Cleveland, $\mathrm{OH})$ which uses Collapse Cone Convolution [cc] algorithm.

\section{Volume Definition}

The Internal GTV (iGTV) was contoured based on acquired 4D CT (Respiratory data sets are "binned" by phase: $0-100 \%$ at $10 \%$ interval). The clinical tumor volume (CTV) defined as Internal Target Volume (ITV) was generated by adding an 8 $\mathrm{mm}$ margin to the iGTV for all histologies. A PTV was generated by adding another $4 \mathrm{~mm}$ margin to the ITV. All OARs were delineated on the average dataset while the lung parenchyme was contoured on the 50\% phase for dose volume evaluation. The planning risk volume (PRV) for the spinal cord was created by adding a $0.5 \mathrm{~cm}$ margin to the contoured spinal cord.

\section{Planning}

The prescription dose for all cases was 70 Gy in 35 fractions given over 7 weeks. The planning objective was to cover the PTV by at least $95 \%$ of the prescribed isodose, and CTV by $98 \%$ of the prescribed isodose line. Identical objectives were set for IMRT and VMAT plans. As previously prescribed radiotherapy was concurrent with chemotherapy, the planning objectives were as follows: The maximum point dose to the spinal cord was less than $45 \mathrm{~Gy}$, Spine $\leq 45 \mathrm{~Gy}$, volume of lung minus GTV receiving more than 20 Gy (V20) $\leq 35 \%, 10 \mathrm{~Gy}(\mathrm{~V} 10) \leq 45 \%, 5$ Gy $(\mathrm{V} 5) \leq 65 \%$, mean lung dose (MLD) $\leq 20 \mathrm{~Gy}$; volume of heart receiving more than $30 \mathrm{~Gy}(\mathrm{~V} 30) \leq 45 \%$, mean heart dose (MLD) $\leq 26 \mathrm{~Gy}$, The maximum point dose to Esophagus $\leq 80 \mathrm{~Gy}$, volume of Esophagus receiving more than 70 Gy (V70) $\leq 20 \%, 50$ gy $(\mathrm{V} 50) \leq 40 \%$, mean Esophagus dose $\leq 34 \mathrm{~Gy}$. The treatment plans were generated utilizing the $6 \mathrm{MV}$ Photon beam from the Varian Triology 120 leaf millennium multileaf collimator (MLC) (Varian Medical Systems, Palo Alto, CA). Plans were delivered with a maximum dose rate of $600 \mathrm{MU} / \mathrm{min}$. All calculations utilized a calculation of grid size of $0.3 \times 0.3 \times 0.3 \mathrm{~cm}^{3}$. In order to rule out interobserver variability, all plans were performed by a single physicist (YS). Figure 1 displays the field arrangements for three different plans.

\section{SSIMRT}

Treated step and shoot IMRT plans were generated according to our clinical practice using 6-8 non coplanar or coplanar beams. Multiple segments (90120) were created using the direct machine parameter optimization (DMPO) algorithm in Pinnacle. ${ }^{12}$

\section{VMAT}

VMAT plans were generated using double partial $\left(180^{\circ}\right)$ arcs with the same isocenter rotating clockwise and counter clockwise starting from $358^{\circ}$ and $178^{\circ}$ with a $15^{\circ}$ and $345^{\circ}$ collimator angle. Each of double partial $\left(180^{\circ}\right)$ arcs was used for planning instead of a whole $360^{\circ}$ arc to reduce lung parenchyma dose. Collimator angle was fixed to $15^{\circ}$ and $345^{0}$ to minimize the effects of interleaf leakage and tongue-and-groove effect. Multiple control points which have 360 segments in double partial arc were created using the smart arc optimization (SmartArc) algorithm in Pinnacle. The control point described gantry speed, dose rate, total treatment time and leaf travel speed. For both the ssIMRT and VMAT plans the same dose objectives and weightings were used.

\section{Hybrid arc IMRT ( HA-IMRT: ssIMRT and VMAT combination)}

The HA-IMRT technique integrates IMRT and VMAT. HA-IMRT plans were generated as a composite plan of $60 \%$ IMRT (IMRT plan for full 70 Gy in 35 fractions) and 40\% VMAT (VMAT consisted of double partial arc plan for full $70 \mathrm{~Gy}$ in 35 fractions) combination. This combination is based on an improvised decision ratio. The aim of combining the both plans with this fixed ratio was to minimize the low dose bath and direct OAR exposure within the fields without compromising from the balance and benefits of both IMRT and VMAT. 
International Journal of Hematology and Oncology

Table 1. Dosimetric comparisons of three planning techniques for local advanced lung cancer patients

\begin{tabular}{|c|c|c|c|c|}
\hline & ssIMRT & VMAT & HA-IMRT & $p$ value \\
\hline $\begin{array}{l}\text { Total Lung } \\
\text { Mean Dose (Gy) }\end{array}$ & 20.31 & 19.82 & 19.83 & $\begin{array}{l}\text { a } 0.060 \\
\text { b } 0.968 \\
\text { c } 0.012\end{array}$ \\
\hline V5 & 55.05 & 63.00 & 58.18 & $\begin{array}{l}\text { a } 0.001 \\
\text { b } 0.001 \\
\text { c } 0.001\end{array}$ \\
\hline V10 & 41.40 & 43.90 & 42.20 & $\begin{array}{l}\text { a } 0.011 \\
\text { b } 0.049 \\
\text { c } 0.011\end{array}$ \\
\hline V20 & 30.06 & 29.30 & 29.8 & $\begin{array}{l}\text { a } 0.002 \\
\text { b } 0.002 \\
\text { c } 0.063\end{array}$ \\
\hline $\begin{array}{l}\text { Ipsilateral Lung } \\
\text { Mean Dose (Gy) }\end{array}$ & 32.07 & 30.61 & 30.92 & $\begin{array}{l}\text { a } 0.001 \\
\text { b } 0.149 \\
\text { c } 0.002\end{array}$ \\
\hline V20 & 55.5 & 52.88 & 53.60 & $\begin{array}{l}\text { a } 0.007 \\
\text { b } 0.140 \\
\text { c } 0.014\end{array}$ \\
\hline V30 & 46.1 & 42.99 & 43.49 & $\begin{array}{l}\text { a } 0.009 \\
\text { b } 0.363 \\
\text { c } 0.014\end{array}$ \\
\hline $\begin{array}{l}\text { Heart } \\
\text { Mean Dose (Gy) }\end{array}$ & 15.92 & 14.81 & 15.20 & $\begin{array}{l}\text { a } 0.027 \\
\text { b } 0.043 \\
\text { c } 0.033\end{array}$ \\
\hline V30 & 21.09 & 17.78 & 18.72 & $\begin{array}{l}\text { a } 0.004 \\
\text { b } 0.845 \\
\text { c } 0.043\end{array}$ \\
\hline $\begin{array}{l}\text { Esophagus } \\
\text { Mean Dose (Gy) }\end{array}$ & 34.50 & 34.15 & 34.27 & $\begin{array}{l}\text { a } 0.548 \\
\text { b } 0.559 \\
\text { c } 0.569\end{array}$ \\
\hline Maximum Dose (Gy) & 75.70 & 74.25 & 74.10 & $\begin{array}{l}\text { a } 0.032 \\
\text { b } 0.710 \\
\text { c } 0.003\end{array}$ \\
\hline V50 & 42.3 & 40.50 & 40.88 & $\begin{array}{l}\text { a } 0.114 \\
\text { b } 0.548 \\
\text { c } 0.559\end{array}$ \\
\hline V70 & 14.03 & 11.76 & 12.35 & $\begin{array}{l}\text { a } 0.131 \\
\text { b } 0.099 \\
\text { c } 0.264\end{array}$ \\
\hline $\begin{array}{l}\text { Spinal cord } \\
\text { Maksimum dose (Gy) }\end{array}$ & 42.36 & 42.07 & 42.04 & $\begin{array}{l}\text { a } 0.665 \\
\text { b } 0.414 \\
\text { c } 0.928\end{array}$ \\
\hline \multicolumn{5}{|l|}{ Clinic Tumor Volume } \\
\hline V77 & 2.15 & 1.74 & 0.55 & $\begin{array}{l}\text { a } 0.583 \\
\text { b } 0.074 \\
\text { c } 0.004\end{array}$ \\
\hline Conformality Index & 1.51 & 1.26 & 1.33 & $\begin{array}{l}\text { a } 0.000 \\
\text { b } 0.001 \\
\text { c } 0.000\end{array}$ \\
\hline Total treatment Time (min) & 292.97 & 108.40 & 199.70 & $\begin{array}{l}\text { a } 0.005 \\
\text { b } 0.005 \\
\text { c } 0.005\end{array}$ \\
\hline Monitor Units & 24805 & 19141 & 22155 & $\begin{array}{l}\text { a } 0.005 \\
\text { b } 0.005 \\
\text { c } 0.005\end{array}$ \\
\hline
\end{tabular}




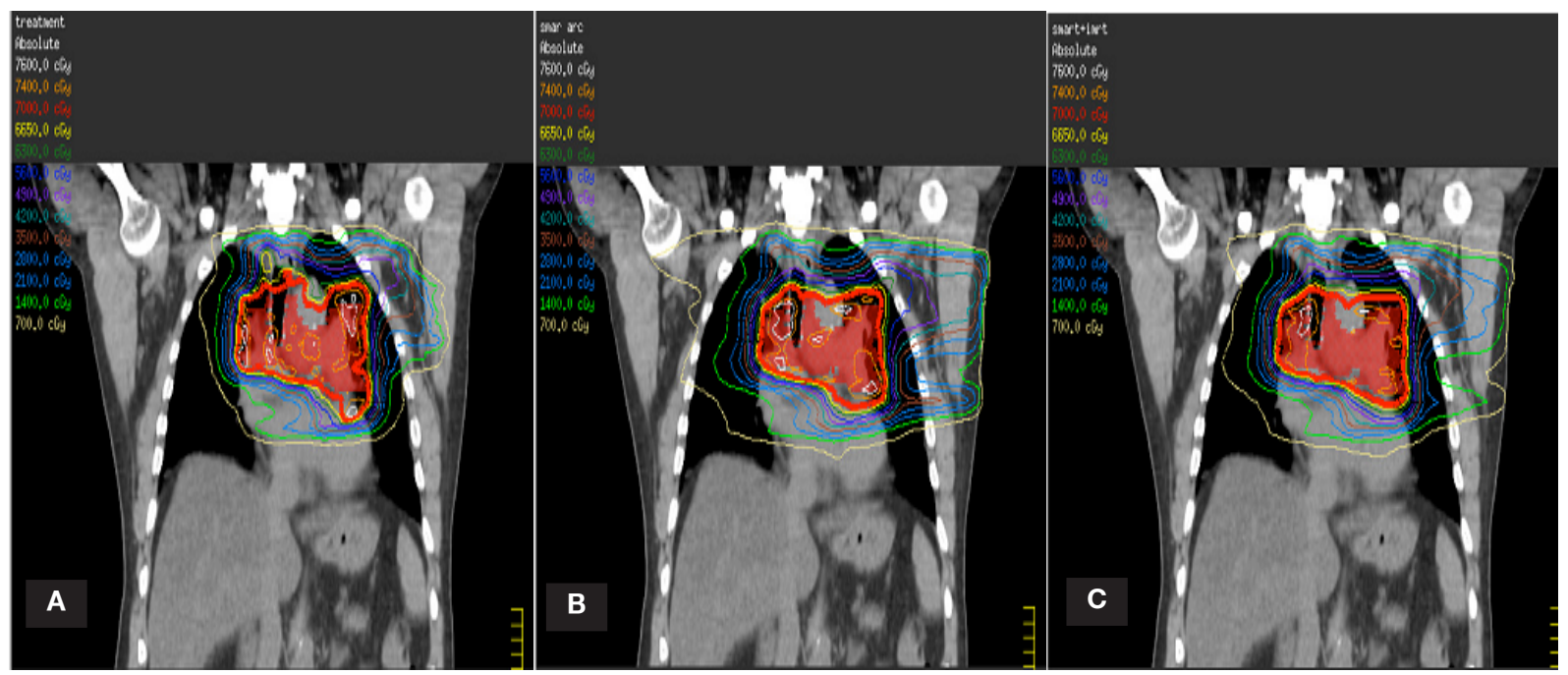

Figure 2. Coronal view of isodose distribution for 70 Gy (a) ssIMRT, (b) VMAT, (c) Hybrid-arc (ssIMRT+VMAT) plans of

a representative patient

The same optimization objectives and planning parameters were used for the HA-IMRT, VMAT, and ssIMRTplans.

\section{Dosimetric Comparison}

The comparison between the plans based on analysis of dose volume histograms was performed for the maximum dose (as Gy) to the spinal cord; V5, V10, V20 for total lung; V20, V30 for the ipsilateral lung; V30 for the heart; V50, V70 for the esophagus. In addition, the conformality index (CI); and V77 for clinical target volume (CTV) were compared for all three techniques. Finally, total treated monitor units (MU: sum of delivery of all fractions); total treatment time (TT: sum of delivery of all fractions) were also compared. The three different techniques were compared, statistically using a two-tailed pair wise Wilcoxon signedranked tests. A value of $p<0.05$ was considered to indicate statistically significant differences.

\section{RESULTS}

Table 1, illustrates the comparisons of the dosimetric parameters for the three different planning techniques: IMRT, VMAT and HA-IMRT. The dose distributions in coronal planes of the three plans are shown in Figure 2.

\section{Lung Doses}

ssIMRT treated less amount of lung to a lower dose compared to VMAT (V5: $55.0 \%$ vs $63.0 \%$, $\mathrm{p}=$ 0.005 ; V10:41.4\% vs $43.9 \% \mathrm{p}=0.018)$. However VMAT yielded lower lung V20 doses (V20:30.6\% vs $29.3 \% \mathrm{p}=0.010$ ). The mean dose to the total lung in the both planes were found to be similar with no significant differences (MLD: $20.3 \%$ vs $19.8 \% \mathrm{p}=$ 0.05). The VMAT technique spared the ipsilateral lung by decreasing V20 and V30 (V20:55.5\% vs $52.8 \% \mathrm{p}=0.008 ; \mathrm{V} 30: 46.1 \%$ vs $42.9 \% \mathrm{p}=0.012$ ).

Hybrid arc was found to be superior in comparison to VMAT in terms of low dose volumes to total lung (V5:58.1\% vs $63.0 \%, \mathrm{p}=.005 ; \mathrm{V} 10: 42.2 \%$ vs $43.9 \%, \mathrm{p}=0.049$ ), while superior to ssIMRT in ipsilateral lung doses (V20:53.6\% vs $55.5 \%, \mathrm{p}=$ 0.007; V30: $43.4 \%$ vs $46.1 \%, p=0.018)$. Mean doses of total lung (TL) and ipsilateral lung (ILL) were lower and also similar to both VMAT and HA-IMRT compared to ssIMRT (TL-19.8 Gy,19.8 Gy, 20.3 Gy,p:0.88; ILL: 30.6 Gy, 30.9 Gy, 32.0 $\mathrm{Gy}, \mathrm{p}=0.139$ ).

\section{Other Organs at Risk}

VMAT allows greater sparing of the heart (V30: $17.78 \%$ vs $21.09 \% \mathrm{p}=0.015$; MHD: $14.81 \%$ vs $15.92 \% \mathrm{p}=0.021)$ in comparison to ssIMRT. Hy- 
brid arc provided significantly better heart $\mathrm{V} 30$ and (mean doses compared to the ssIMRT was used here alone).

The maximum dose to the spinal cord was less than $45 \mathrm{~Gy}$, and was obtained in all of the plans regardless of planning technique (42.3 Gy for IMRT, 42.0 Gy for VMAT and 42.0 Gy for HA-IMRT).

All three plans provided acceptable and comparable esophagus DVH results, V50, V70, maximum and mean doses.

\section{Delivery}

The CI was $1.51,1.26$ and 1.33 for IMRT, VMAT and HA-IMRT planning, respectively (Table 1). VMAT was proved to be more conformal respect to the CI values $(\mathrm{p}=0.005)$, faster (108 min vs 293 min, $\mathrm{p}=0.005)$ with lower MUs (19141vs 24805 $\mathrm{p}=0.005$ ) in comparison to ssIMRT. Hybrid arc was found to be superior to ssIMRT in terms of total treatment time (199 min vs $293 \mathrm{~min}, \mathrm{p}=0.005$ ) with lower MU (22155 vs $24805, \mathrm{p}=0.005)$. Overall, HA-IMRT provided more homogenous dose distrubiton (CTV V77:0.55\% vs $2.1 \%$ vs $1.7 \%$, $\mathrm{p}=$ 0.004 ) in comparison to IMRT, but it was similar to VMAT alone $(\mathrm{p}=0.074)$.

\section{DISCUSSION}

Radiotherapy plays an indispensable role in treating locally advanced NSCLC. ${ }^{3}$ The innovations in the radiation therapy of NSCLC such as IMRT and VMAT, compared with previous 3DCRT methods, can deliver higher doses, more conformably and precisely to the tumor while minimizing doses to organs at risk. These factors could possibly lead to decrease morbidity and increased local control. Therefore, dose escalation has been a topic investigated using 3DCRT, IMRT, and particle therapy in ongoing randomized trials for stage III NSCLC. ${ }^{2}$ VMAT is a novel radiation technique, which can achieve highly conformal dose distributions with improved target volume coverage and sparing of normal tissues compared with conventional radiotherapy techniques. In this study, we compared our routine ssIMRT with VMAT and HA-IMRT techniques. We investigated the clinically practi- cal and implementable combination of VMAT and ssIMRT to see if there was improvement in conformity, better sparing of OARs, and to decrease treatment time and to avoid the low dose bath. This study revealed that HA-IMRT could combine the benefits of IMRT and VMAT to deliver a faster, more conformal, homogeneous treatment in comparison to ssIMRT with less amount of lung irradiated to a lower dose in comparison to VMAT. Our study is different than other hybrid studies because we are trying to optimize together with each treatment techniques in total dose and OAR constraints such as simultaneously integrated treatment techniques. ${ }^{11,24}$

IMRT studies have shown improvements over 3DCRT planning with respect to tumor dose escalation and doses to OARs. ${ }^{13}$ However, this gain seemed to be at a cost of longer treatment time which could lead to intra-fraction variations. ${ }^{11,14}$ In our analyses, HA-IMRT reduced the total treatment time, such as almost one third (33\%), in comparison to ssIMRT.

The clinical use of VMAT has been increasing significantly and the majority of published data on VMAT consist of planning and feasibility studies. The clinical outcome is maturing in several sites including prostate, pelvis (lower gastrointestinal, gynecological), head and neck, thoracic, central nervous system, breast and other tumor sites. ${ }^{15}$ Double arcs instead of a single arc have been shown to provide more homogenous and conformal dose distribution in thoracic malignancies, ${ }^{8}$ We also used double arcs VMAT in this study by rotating it clockwise and counter clockwise starting from $358^{\circ}$ and $178^{\circ}$ (collimator angle was $15^{\circ}$ ).

Esophagitis, in the radiation treatment of locally advanced lung cancer, is a major dose-limiting acute side effect directly related with the volume treated. ${ }^{14,16}$ Multiple studies have shown the potential help for esophageal sparing with IMRT over 3 -DCRT. ${ }^{16,17}$ The strongest predictors of esophageal toxicity was found to be $\mathrm{V} 10<65 \%$ and esophageal Dmax $>55$ Gy.[18] Esophagus sparing is also found in the literature to be obtained by using VMAT planning. ${ }^{18}$ In our study we kept the maximum esophageal doses similar to each technique and were lower than $55 \mathrm{~Gy}$. Therefore no significant difference was found in terms of this organ. 
The second major concern has been pneumonitis which is dose limiting. As IMRT plans have reduced V5, V10, V20 and MLD in comparison to 3D-CRT plans, Yom et al noted a fourfold decrease in grade 3 or more pneumonitis by IMRT despite larger gross tumor volume ( $8 \%$ vs $32 \%$ ) while they concluded that the most effective indicator for pneumonitis was keeping V5<60 Gy [19]. The toxicity rates was also reported to be significantly lower in the IMRT and 4D-CT group than in the 3D-CRT group. ${ }^{20}$ IMRT field number was recommended to be 5 or fewer in order not to increase the irradiated low dose volume, ${ }^{16}$ while three, five and seven-beam arrangements were noted to have similar MLD, V13, V20 and V30 values. ${ }^{21}$ There has been efforts to try decreasing the irradiated low dose volume of lung such as Mayo et al using a hybrid-IMRT technique which combined 3-DCRT with IMRT, and showed to lower the contralateral lung V5, V13 and V20. ${ }^{11}$ Chan et al tried VMAT and 3-DCRT (Hybrid-rapid arc) combination, and Hybrid-rapid arc produced the lowest V20 and MLD in comparison to 3-DCRT or VMAT alone without any statistical difference in the low dose volumes like V5, V10, V15. ${ }^{7}$ We have revealed V5 as $55 \%, 63 \%, 58.8 \%$ for IMRT, VMAT and HAIMRT plans, respectively. Even we have low V5 dose levels under the criteria defined by the given reference ${ }^{19}$ Our results have shown the balancing effect of combined planning if needed in clinical practice. In order to fill the gap between IMRT and VMAT, different search has also been going on as Kim et al worked on increasing the angular sampling of radiation beams while eliminating dispensable segments of the incident fields to improve conformity in dose distributions while maintaining high delivery efficiency. ${ }^{22}$

In our planning study, we attempted to minimize the disadvantage of VMAT in irradiating low dose volume by using a combination with IMRT. HAIMRT seemed to be a better approach in comparison to the VMAT alone and IMRT alone based on better or similar OAR sparing and conformality. Also better dose modulation and dose fall off around the PTV could be the advantange of hybrid treatment technique compare to VMAT. One way of measuring the dose-modulation potential of a plan delivery modality is to consider the allowed number of control points, which are created by the TPS software and contained in a treatment plan's DICOM file. Each control point specifies the state of the linac at a given instant of treatment such as jaw settings, MLC positions, MUs, gantry angle and rotation speed. An IMRT plan and double partial arc VMAT plan contain 320 and 178 control points, respectively while a hybrid plan contains $818(2 \times 320+178)$ control points. ${ }^{23}$

This work is solely a dosimetric comparison of planning options. Clinical implementation would unfortunately require two separate physics plans of VMAT and IMRT to reach a composite in two courses. Therefore our effort was just to encourage thinking about the hybrid combination of IMRT and VMAT in future planning algorithms to combine them in one fraction. We have not aimed to accept this combination as a standard approach to all cases, because it also accepts a tradeoff from the beginning such as compromising from the lower lung V5 or V10 doses in IMRT in order to get a faster and acceptable plan with HA-IMRT where we could not ensure acceptable lung doses in VMAT alone. However, we should emphasize that this combination stands as a viable option once required. ${ }^{24}$

The ratio of ssIMRT to VMAT in our study is an improvised ratio due to the fact that planning process can be time consuming and currently physicist is dependent in our planning HA-IMRT method, where an automatic algorithm could provide different solutions of combinations for specific individualized dosimetric endpoints requiring hybrid planning in one fraction, such as whether to prioritize the CI or the lung V20 or esophagus based on the individual tumor of the patients.

\section{Conclusion}

Our results suggest that focusing on HA-IMRT in near future treatment planning systems with optimization and delivery of arcs and static IMRT fields in the same fraction delivery could be a rationale solution to combine the benefits of ssIMRT and VMAT to deliver a faster, more conformal, and homogeneous treatment in comparison to ssIMRT and to irradiate less amount of lung to a lower dose in comparison to VMAT. 


\section{REFERENCES}

1. Gadgeel SM. The optimal chemotherapy for stage III nonsmall cell lung cancer patients. Curr Oncol Rep 13: 272-279, 2011.

2. van Meerbeeck JP, Meersschout S, De Pauw R, Madani I, De Neve W: Modern radiotherapy as part of combined modality treatment in locally advanced non-small cell lung cancer: present status and future prospects. Oncologist 13: 700-708, 2008.

3. Machtay M, Paulus R, Moughan J, et al Defining Local-Regional Control and Its Importance in Locally Advanced Nonsmall Cell Lung Carcinoma: A Radiation Therapy Oncology Group Analysis. J Thorac Oncol 7: 716-722, 2012.

4. Bradley JD, Paulus R, Komaki R, et al: Standard-dose versus high-dose conformal radiotherapy with concurrent and consolidation carboplatin plus paclitaxel with or without cetuximab for patients with stage IIIA or IIIB non-small-cell lung cancer (RTOG 0617): a randomised, two-by-two factorial phase 3 study. Lancet Oncol 16: 187-199, 2015.

5. Jiang ZQ, Yang K, Komaki R, et al: Long-term clinical outcome of intensity-modulated radiotherapy for inoperable nonsmall cell lung cancer: the MD Anderson experience. Int $\mathrm{J}$ Radiat Oncol Biol Phys 83: 332-339, 2012.

6. Chun SG, Hu C, Choy H, et al: Impact of Intensity-Modulated Radiation Therapy Technique for Locally Advanced NonSmall-Cell Lung Cancer: A Secondary Analysis of the NRG Oncology RTOG 0617 Randomized Clinical Trial. J Clin Oncol 35: 56-62, 2017.

7. Chan OS, Lee MC, Hung AW, et al. The superiority of hybridvolumetric arc therapy (VMAT) technique over double arcs VMAT and 3D-conformal technique in the treatment of locally advanced non-small cell lung cancer--a planning study. Radiother Oncol 101: 298-302, 2011.

8. Jiang $X, L i T$, Liu $Y$, et al. Planning analysis for locally advanced lung cancer: dosimetric and efficiency comparisons between intensity-modulated radiotherapy (IMRT), single-arc/ partial-arc volumetric modulated arc therapy (SA/PA-VMAT). Radiat Oncol 6: 140, 2011.

9. Quan EM, Chang JY, Liao Z, et al. Automated VMAT treatment planning for stage III lung cancer: how does it compare with IMRT? Int J Radiat Oncol Biol Phys 84(1): e69-76, 2012.

10. Zhang J, Yu XL, Zheng GF, Zhao F. Intensity-modulated radiotherapy and volumetric-modulated arc therapy have distinct clinical advantages in non-small cell lung cancer treatment. Med Oncol 32: 94, 2015. doi: 10.1007/s12032-015-0546-6

11. Mayo CS, Urie MM, Fitzgerald TJ, et al. Hybrid IMRT for treatment of cancers of the lung and esophagus. Int $\mathrm{J}$ Radiat Oncol Biol Phys 71(5):1408-1418, 2008.
12. Bergman AM, Bush K, Milette MP, et al. Direct aperture optimization for IMRT using Monte Carlo generated beamlets. Med Phys 33: 3666-3679, 2006.

13. Murshed H, Liu HH, Liao Z, et al: Dose and volume reduction for normal lung using intensity-modulated radiotherapy for advanced-stage non-small-cell lung cancer. Int J Radiat Oncol Biol Phys 58: 1258-1267, 2004.

14. Schwarz M, Alber M, Lebesque JV, et al. Dose heterogeneity in the target volume and intensity-modulated radiotherapy to escalate the dose in the treatment of non-small-cell lung cancer. Int J Radiat Oncol Biol Phys 62: 561-570, 2005.

15. Teoh M, Clark $\mathrm{CH}$, Wood K, et al. Volumetric modulated arc therapy: a review of current literature and clinical use in practice. Br J Radiol 84: 967-996, 2011.

16. Liu $H H$, Wang $X$, Dong $L$, et al. Feasibility of sparing lung and other thoracic structures with intensity-modulated radiotherapy for non-small-cell lung cancer. Int J Radiat Oncol Biol Phys 58(4):1268-1279, 2004.

17. Grills IS, Yan D, Martinez AA, et al. Potential for reduced toxicity and dose escalation in the treatment of inoperable nonsmall-cell lung cancer: a comparison of intensity-modulated radiation therapy (IMRT), 3D conformal radiation, and elective nodal irradiation. Int J Radiat Oncol Biol Phys 57(3):875-890, 2003.

18. Jeremic B, Milicic B, Milisavljevic S, et al.Toxicity of concurrent hyperfractionated radiation therapy and chemotherapy in locally advanced (stage III) non-small cell lung cancer (NSCLC): single institution experience in 600 patients. Clin Transl Oncol 14: 613-618, 2012

19. Yom SS, Liao Z, Liu HH, et al: Initial evaluation of treatmentrelated pneumonitis in advanced-stage non-small-cell lung cancer patients treated with concurrent chemotherapy and intensity-modulated radiotherapy. Int J Radiat Oncol Biol Phys 68: 94-102, 2007.

20. Liao ZX, Komaki RR, Thames HD, et al. Influence of technologic advances on outcomes in patients with unresectable, locally advanced non-small-cell lung cancer receiving concomitant chemoradiotherapy. Int J Radiat Oncol Biol Phys 76: 775-781, 2010.

21. Chapet O, Fraass BA, Ten Haken RK. Multiple fields may offer better esophagus sparing without increased probability of lung toxicity in optimized IMRT of lung tumors. Int J Radiat Oncol Biol Phys 65: 255-265, 2006.

22. Kim H, Li R, Lee R, et al. Dose optimization with first-order total-variation minimization for dense angularly sampled and sparse intensity modulated radiation therapy (DASSIM-RT). Med Phys 39: 4316-4327, 2012. 
International Journal of Hematology and Oncology

23. Amaloo C, Nazareth DP, Kumaraswamy LK. Comparison of hybrid volumetric modulated arc therapy (VMAT) technique and double arc VMAT technique in the treatment of prostate cancer. Radiology and oncology 49: 291-298, 2015.

24. Zhao N, Yang R, Wang J, et al. An IMRTMMAT Technique for Nonsmall Cell Lung Cancer. BioMed Res Int 2015, 2015:613060. doi: 10.1155/2015/613060

\section{Correspondence:}

Dr. Ugur SELEK

Koc Üniversitesi TPp Fakültesi

Radyasyon Onkolojisi Anabilim Dali

Davutpasa Caddesi, No: 4

34010, Topkapi, ISTANBUL / TURKEY

Tel: (+90-537) 7243724

Fax : +90 2123112395

e-mail: uselek@mdanderson.org, ugurselek@yahoo.com, ugurs@amerikanhastanesi.org 